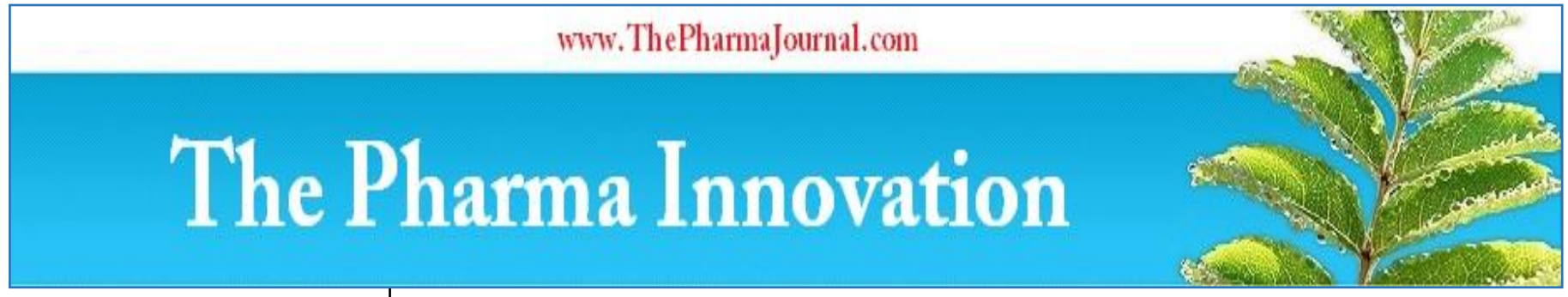

ISSN (E): 2277 - 7695

ISSN (P): 2349-8242

NAAS Rating: $\mathbf{5 . 0 3}$

TPI 2020; SP-9(7): 16-18

(C) 2020 TPI

www.thepharmajournal.com

Received: 13-05-2020

Accepted: 15-06-2020

\section{Raghavendran VB}

Assistant Professor (Veterinary

\& Animal Sciences), ICAR-

KVK, Sirugamani, Tamil Nadu, India

\section{Rajasokkapan S}

Veterinary Assistant Surgeon,

Malayandigoundanur,

Udumalaipettai, Tamil Nadu,

India

\section{Prabhu R}

Technical Officer, AVIAGEN, Udumalaipettai, Tamil Nadu, India

\section{Prevalnce of sub-clinical mastitis in lactating cows in Thoothukudi district}

\author{
Raghavendran VB, Rajasokkapan S and Prabhu R
}

DOI: $\underline{\text { https://doi.org/10.22271/tpi.2020.v9.i7Sa.4898 }}$

\begin{abstract}
Twenty four dairy farms were selected to determine the prevalence of subclinical mastitis in lactating cows of Thoothukudi district. Milk samples from all the four quarters were collected separately and were subjected to physical examination and subsequently screened for Sub-Clinical Mastitis using California Mastitis Test. The prevalence was more in crossbred cows than the nondescript. The incidence of SCM was highly prevalent in the hind quarters $(63 \%)$ of the lactating cows udder than the fore quarters (31\%). The SCM prevalence was higher in the cows maintained under intensive management system than semiintensive management system. The overall prevalence of SCM was recorded $33.33 \%, 73.53 \%$ and $85.71 \%$ in non-descript, Jersey CB and HF CB cows respectively. During the early, mid and late stages of lactation, the prevalence of SCM was $56.82 \%, 60.00 \%$ and $56.28 \%$ respectively in the lactating cows. It was noticed during the study that the farmers are not well aware of SCM and their impact on milk production and udder health. Hence, imparting proper knowledge about the adoption of strict hygiene will reduce the prevalence of SCM which in turn increases the production and profit of the farmers.
\end{abstract}

Keywords: Sub-clinical mastitis, lactating cows, milk

\section{Introduction}

Mastitis affected dairy cattle causes a great economic losses from reduction on milk production, treatment costs, milk withheld following treatment and occasionally death. Subclinical mastitis (SCM) is the one where no changes in the milk are perceptible might reduce milk production, increase the somatic cell count, which requires specific detection methods such as the California Mastitis Test ${ }^{[1]}$. The diagnosis of SCM is more problematic since the milk appears normal but usually has an elevated somatic cell count. It is important by the way it reduces the milk yield, usually precedes the clinical form, persist for long time, difficult to detect and it adversely affects milk quality ${ }^{[2]}$. The milk yield of the cows affected with SCM will have reduction in both quantity and quality ${ }^{[3]}$. Average decrease in milk yield due to clinical and subclinical mastitis was estimated to be $50 \%$ and $17.5 \%$, respectively. The present study was undertaken with the aim to detect the prevalence of SCM in lactating cows in dairy farms in Thoothukudi district.

\section{Materials and Method}

Twenty four dairy farms were selected to determine the prevalence of SCM in lactating cows in Tuticorin district. The samples were collected from the animals in various stages of lactation. Before collection of milk the teat and tips were washed with clean water, antisepsis was done with a swab soaked with $70 \%$ alcohol and then milk sample were collected aseptically from the udder at the time morning milking. Immediately after collection, milk samples were subjected to physical examination with naked eyes to detect any abnormalities in color, consistency and presence of any other clot, blood, flakes and other visible abnormalities.

\section{Questionnaire-based data collection and processing}

Data from each animal and herd were collected using a questionnaire. Parameters studied were age, breed, number of parity, lactation stage and per day milk production. Age, parity, lactation stage were obtained from farm records. The statistical analysis of collected data was performed by using SPSS version 11.5.
Corresponding Author:
Raghavendran VB

Assistant Professor (Veterinary

\& Animal Sciences), ICAR-

KVK, Sirugamani, Tamil Nadu,

India 


\section{Subclinical Mastitis by California Mastitis Test (CMT)}

For detection of subclinical mastitis the procedure was followed in this study were as per manufacturer's instruction (DE LAVEL, Ltd). The California Mastitis Test (CMT) is a rapid, accurate, animal side test to help determine somatic cell counts (SCC). A squirt of milk, about $3 \mathrm{ml}$ from each half was placed in each of 2 shallow cups in the CMT paddle. An 3ml equal amount of the commercial CMT reagent was added to each cup. A gentle circular motion was applied to the mixtures in a horizontal plane for 10-15 seconds. Based on the thickness of the gel formed by CMT reagent-milk mixture, test results were scored as 0 (negative/trace), +1 (weak positive), +2 (distinct positive), +3 (strong positive) and +4 (very strong positive) ${ }^{[4]}$. Positive CMT-cows were defined as having at least one CMT-positive quarter.

\section{Results and Discussions}

The samples collected from organized farm were examined by CMT reagent and showed overall prevalence of SCM as 58\%. Findings of the present study are in concurrence with earlier findings in Bangladesh ${ }^{[5]}$ and India ${ }^{[6]}$ respectively.

\section{Breed related prevalence}

The Holstein Friesian crossbred showed $85.71 \%$ positive reaction whereas Jersey crossbred and nondescript showed $73.53 \%$ and $15.79 \%$, respectively. The results were in concurrence with other findings ${ }^{[7-10]}$. This is primarily due to less genetic resistance to infection and inadaptability to local weather conditions ${ }^{[11]}$. However, more studies are needed to shed more light on this differential udder infection rates between local and cross breeds.

\section{Age wise prevalence}

The prevalence of SCM in native breeds were $20.0 \%, 60.0 \%$, $13.4 \%$ and $6.6 \%$, respectively and $25.5 \%, 32.6 \%, 23.3 \%$ and $18.6 \%$ respectively at the age group of 3 years to 5 years, 5 years to 8 years, 8 years to 12 years and above 12 years. Several authors reported an increase in mastitis frequency with age $[12,13]$. The results were in agreement with those reported by these authors as 5-8 years old cows (15.43\%) were susceptible to subclinical mastitis than those of 2-4 years $(3.71 \%)$.

\section{Parity related prevalence}

The prevalence of SCM was recorded as $13.4 \%, 26.4 \%$, $33.4 \%, 20.0 \%$ and $6.66 \%$ in native breeds and $9.3 \%, 28.0 \%$, $23.2 \%, 20.9 \%$ and $11.6 \%$ in crossbreds during the parity numbers 2, 3, 4, 5 and 6 respectively. It indicates that the prevalence of SCM was found highest at third parity in local and crossbreed cows. The increase in the milk yield as parity increases make it more prone for SCM. The advancement in parity increases the incidence of SCM ${ }^{[14,15]}$.

\section{Lactation stage related prevalence}

In all three stages of lactation in both the local cows and cross breed cows affected with SCM. The prevalence of SCM was recorded in $53.3 \%, 33.3 \%$ and $13.3 \%$ in local breed cows, and $39.53 \%, 32.5 \%$ and $27.9 \%$ in cross breed cows during the early, mid and late stages of lactation, respectively. The overall prevalence of SCM on the basis of lactation stage in cows showed that all the three lactation stages had SCM but there was a tendency to decrease the prevalence of SCM from early $(43.1 \%)$ to mid $(32.76 \%)$ and late stage $(24.14 \%)$.

It indicates that the prevalence of SCM was found highest at early stage in both the local (53.3\%) and cross breed (39.53\%) cows in comparison to mid and late stages of lactations. There results contradicts the earlier finding of [16], who reported highest prevalence of SCM during the third month of lactation. However, these results agree with ${ }^{[17]}$ who reported lower prevalence of SCM in stages of lactation above five months. The reason correlates to enlarged status of udder which is particularly prone to infection.

\section{Relation between positive CMT and degree of quarter attack}

Results of positive CMT realized on quarters showed that 232 out of $400(58.0 \%)$ quarters were reached with variable degree of attack with subclinical mastitis. It was found that 33 out of the totally 400 quarters $(8.25 \%)$ showed degree (++++), 47 ones $(11.75 \%)$ showed degree $(+++), 54$ ones $(13.5 \%)$ showed degree $(++), 98$ ones $(24.5 \%)$ showed degree $(+)$ and the rest $(42.0 \%)$ showed degree $(-)$. The results were in accordance with same research findings (18). Subclinical mastitis was more common in hind quarters than in front quarters ${ }^{[19]}$.

\section{Conclusion}

The obtained prevalence may be attributed to a group of shared factors of breeding and environmental condition. On the other hand, good management practices minimize the occurrence of the disease. It was concluded the CMT could be used to monitor udder health and mastitis control programs. It is particularly important that milkers be aware of any standard procedures for identifying cows to sample as well as appropriate sampling procedures. In a spite of a large research efforts aimed to gain epidemiological knowledge and to develop a new control tools for mastitis, the clinical occurrence of this disease remains a substantial problem for dairy producers.

\section{References}

1. Iraguha B, Hamudikuwanda H, Mushonga B, Kandiwa E, Mpatswenumugabo JP. Comparison of cow-side diagnostic tests for subclinical mastitis of dairy cows in Musanze district, Rwanda. J Afr Vet Assoc. 2017; 88:e16. doi: 10.4102/jsava.v88i0.1464

2. Seegers H, Fourichon C, Beaudeau F. Production effects related to mastitis and mastitis economics in dairy cattle herds. Vet Rese. 2003. 34:475-491.

3. Bobbo T, Ruegg PL, Stocco G, Fiore E, Gianesella M, Morgante $\mathrm{M}$ et al. Associations between pathogenspecific cases of subclinical mastitis and milk yield, quality, protein composition, and cheese-making traits in dairy cows. J Dairy Sci, 2017; 100:4868-4883.

4. Ikram M. Diagnostic microbiology. In: W Paul and V M D Pratt (editors), Laboratory Procedures for Veterinary Technicians. R R Donnelley and Sons Company. St. Louis, Missouri. 1997, 159-160.

5. Kader MA, Samad MA, Saha S, Taleb MA. Prevalence and aetiology of sub-clinical mastitis with antibiotic sensitivity to isolated organisms among milch cows in Bangladesh. Ind J Dairy Sci. 2002; 55:218-223.

6. Singh KB, Baxi KK. Studies on the incidence and diagnosis of sub-clinical mastitis in milch animals. Indian Vet J. 1988; 47:723-729.

7. Dego OK, Tareke F. Bovine Mastitis in Selected Areas of Southern Ethiopia. Trop. Anim. Health Prod. 2003; 35:197. 
8. Ghazi K, Niar A. Incidence of mastitis in various bovine breedings in Tiaret area (Algeria). Assiut Vet. Med. J. 2006; 52:198

9. Mdegela RH, Ryoba R, Karimuribo ED, Phiri EJ, Løken T, Reksen O, Mtengeti E et al. Prevalence of clinical and subclinical mastitis and quality of milk on smallholder dairy farms in Tanzania. J S Afr Vet Assoc. 2009; 80(3):163-168.

10. Ahmed Abdel-Rady, Mohammed Sayed. Epidemiological Studies on Subclinical Mastitis in Dairy cows in Assiut Governorate Veterinary World. 2010; 10:373-380

11. Payne WJA, Wilson RT. An introduction to Animal Husbandry in the Tropics. 5th Ed. Blackwell Publishing Ltd, Iowa State University Press USA, 1999, 826

12. Schultz IM. Somatic cell counting of milk in production testing programs control technique. J Amer. Vet. Med. Assoc. 1977; 170:1244.

13. Bendixen PH, Vilson B, Ekesbo I, Astrand DB. Disease frequencies in dairy cows in Sweden VI. Tramped teat. Prev. Vet. Med. 1988; 6:17

14. Rasool G, Jabbar MA, Kazmi SE, Ahmed A. Incidence of sub-clinical mastitis in Nilli-Ravi buffaloes and Sahiwal cows. Pak Vet J. 1985; 5:76-78.

15. Devi BK, Shukla PC, Bagherwal RK. Incidence of subclinical mastitis in cows. Indian J Dairy Sci. 1997; 50:477-478.

16. Rahman MS, Nooruddin M, Rahman MM. Prevalence and distribution of mastitis in cross-bred and exotic dairy cows. Bangladesh Veterinary Journal. 1997; 14:1-4.

17. Pal P, Verma BB. Some observation on efficacy of indirect test for detection of sub-clinical mastitis. Indian $\mathbf{J}$ Vet Med. 1988; 8:40-41.

18. Attia ERH, El-Rashidy, Amal A, Metias KN. Comparative study between electric conductivity, California mastitis test and somatic cell count for rapid diagnosis of subclinical mastitis in lactating cows. 7th Sci. Cong. Egyptian Society for Cattle Diseases, Assiut, Egypt. 2003, 25

19. Ndahetuye JB, Persson Y, Ann-Kristin Nyman, Tukei M, Ongol MP, Renée Båge. Aetiology and prevalence of subclinical mastitis in dairy herds in peri-urban areas of Kigali in Rwanda. Tropical Animal Health and Production. 2019; 51:2037-2044. 